\title{
Effects of Three Types of Separator Membranes on the Microbial Fuel Cells Performance
}

\author{
Zhang Songhe*. \\ Ministry of Education Key Laboratory of Integrated \\ Regulation and Resource Development on Shallow Lakes \\ College of Environment, Hohai University \\ Nanjin, China. \\ Shzhang@hhu.edu.cn
}

\section{Hui Yuxin}

Ministry of Education Key Laboratory of Integrated Regulation and Resource Development on Shallow Lakes College of Environment, Hohai University Nanjin, China. hyx0824@126.com

\begin{abstract}
Separator membrane in microbial fuel cell (MFC) is one of the main structures and could significantly affect the performance and the cost of MFCs. Proton exchange membranes (PEMs) are typically used in two-chamber microbial fuel cells (MFCs) to separate the anode and cathode chambers while to allow protons transferring from anode to the cathode. Three types of separator membranes (Proton Exchange Membrane, $M_{H} ; 0.22 \mu m$ Synthetic Fabric Membrane, $M_{0.22} ; 0.015 \mu m$ Track-Etch Membrane, $M_{0.015}$ ) were used in microbial fuel cell (MFC) to investigate their effect on MFC performance in this study. Membrane internal resistance, membrane biofouling and oxygen diffusion were analyzed. Results from imaging analysis coupled with FTIR, SEM and EDX demonstrated that the fouling layer attached on membranes consisted of microorganisms encased in extracellular polymers and inorganic salt precipitations. $M_{0.22}$ had a best maximum power density among three kinds of membranes, and the cost of $M_{0.22}$ is the lowest. Therefore, $M_{0.22}$ might be a promising membrane to be used in MFC.
\end{abstract}

Keywords-component; power density; internal resistance; membranes; membrane fouling; microbial fuel cells (MFC).

\section{INTRODUCTION}

Microbial fuel cells (MFCs) are considered as a promising and novel approach without pollution to convert organic wastes to capture energy in the form of electricity or hydrogen gas by applying microorganisms as bicatalyst ${ }^{[1]}$. MFC systems can convert a portion of the chemical energy within organic matter to usable biogenic electrical energy and are generally considered as a new technology for sustainable development ${ }^{[2-4]}$. MFCs can also be used for biosensor ${ }^{[5]}$, remote monitoring ${ }^{[6]}$, algae and plants producing electric ${ }^{[7]}$, algae oil ${ }^{[8]}$, waste water treatment $^{[9 ; 10]}$

Separator membranes are considered as the key

\author{
Han Bing \\ Ministry of Education Key Laboratory of Integrated \\ Regulation and Resource Development on Shallow Lakes \\ College of Environment, Hohai University \\ Nanjin, China. \\ 304732166@qq.com
}

component of MFCs. The main function of the separator membranes in two-chambered MFCs is to separate the anode and cathode chambers, membranes allow protons to transport to the cathode in order to sustain an electrical current $^{[11]}$. The major problems associated with membrane separators in MFCs are membranes biofouling, which limite proton transfer rate and high membrane $\operatorname{costs}^{[12 ; 13]}$.

According to recent study, membrane biofouling was caused by the microorganisms, extracellular polymers and inorganic salts during the long-term operation of MFC, and this would deteriorate the MFC performance ${ }^{[14 ; 15]}$. In additions, it is considered that membrane biofouling has less influence on the increasing of electrical resistance of Nafion than the cation's occupation of sulfonate functional group ${ }^{[16]}$.

Internal resistance in MFC system is the main contributor to this low power density, which is mostly affected by membranes biofouling. Until now, most two chamber MFCs have used a proton exchange membrane (PEM, typically Nafion ${ }^{\circledR 117}$ ) and several have used an anion exchange membrane ${ }^{[17]}$. In general, PEM is expensive and occupy about $38 \%$ capital cost of MFCs ${ }^{[18]}$

In this study, the effects of three separator membranes on biofouling of membranes, internal resistance, power generation, Chemical Oxygen Demand (COD) removal, and the columbic efficiency of MFC were investigated ${ }^{[17]}$.

\section{MATERIALS AND METHODS}

\section{A. Membrane selection and growth media}

Three types of membrane were used to investigate the effect of membrane on MFC performance. These included PEM (N117CS, DuPont), $0.22 \mu \mathrm{m}$ Synthetic Fabric Membrane $\left(\mathrm{M}_{0.22}\right.$, Shanghai Xinya Purifier Devices 
Factory) and $0.015 \mu \mathrm{m}$ Track-Etch Membrane $\left(\mathrm{M}_{0.015}\right.$, $\Phi 3 \mathrm{~cm}$, Whatman). The PEM is consisted of a hydrophobic fluorocarbon backbone $\left(-\mathrm{CF}_{2}-\mathrm{CF}_{2}-\right)$ and hydrophilic sulfonate groups $\left(\mathrm{SO}_{3}^{2-}\right) .0 .22 \mu \mathrm{m}-\mathrm{SFM}(\Phi 3 \mathrm{~cm})$ are made from cellulose acetate and cellulose nitrate. The last type is $0.015 \mu \mathrm{m}$-TEM, uclepore track-etch membrane.

About $100 \mathrm{ml}$ excess sludge from wastewater plant cultured in each MFC was used as microbial bioanodes. (Fig .1). Both cathode and anode compartments of all MFCs were filled with $50 \mathrm{mM}$ phosphate buffer solution

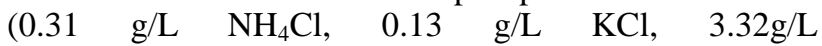
$\left.\mathrm{Na}_{2} \mathrm{HPO}_{4} \cdot 12 \mathrm{H}_{2} \mathrm{O}, 10.32 \mathrm{~g} / \mathrm{L} \mathrm{NaH} \mathrm{PO}_{4} \cdot 2 \mathrm{H}_{2} \mathrm{O}, \mathrm{pH}=7.0\right)$, and add $1 \mathrm{ml}$ per liter trace elements electrode $\operatorname{buffer}\left(\mathrm{CoCl}_{2} \bullet 6 \mathrm{H}_{2} \mathrm{O}, \quad 0.10 \mathrm{~g} / \mathrm{L} ; \quad \mathrm{CuSO}_{4} \cdot 5 \mathrm{H}_{2} \mathrm{O}, \quad 0.01 \mathrm{~g} / \mathrm{L}\right.$; $\mathrm{MnSO}_{4} \cdot \mathrm{H}_{2} \mathrm{O}, \quad 0.50 \mathrm{~g} / \mathrm{L} ; \mathrm{NaCl}, \quad 1.00 \mathrm{~g} / \mathrm{L} ; \mathrm{CaCl}_{2} \cdot 2 \mathrm{H}_{2} \mathrm{O}$, $0.10 \mathrm{~g} / \mathrm{L} ; \mathrm{MgSO}_{4} \cdot 7 \mathrm{H}_{2} \mathrm{O}, 3.00 \mathrm{~g} / \mathrm{L} ; \mathrm{ZnCl}_{2}, 0.13 \mathrm{~g} / \mathrm{L} ; \mathrm{FeSO}_{4}$, $0.10 \mathrm{~g} / \mathrm{L})^{[19]}$. The anode feed with glucose $\left(\mathrm{COD}_{\mathrm{int}}=1000 \mathrm{ml} / \mathrm{l}\right)$.

\section{B. MFC construction}

The MFC was a dual-chamber configuration with the anode and cathode in a $288 \mathrm{~mL}$ chamber (Fig .1). The top of anode-chamber had two ports for sampling and introducing electrodes, and the ports were sealed with thick rubber stoppers during operation. The anode was made by a carbon fiber felt $\left(4 \times 2 \mathrm{~cm}^{2}\right.$, Q-CARBON MATERIAL CO., China). The cathode was carbon paper with $\mathrm{Pt}$ on it $\left(4 \times 2 \mathrm{~cm}^{2}, 1 \mathrm{mg} / \mathrm{cm}^{2}\right.$, River's electric co., LTD., Shanghai, China). All exposed metal surfaces were sealed with a nonconductive epoxy resin.

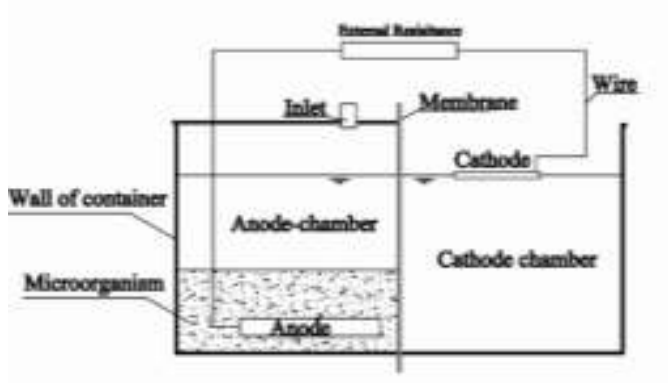

Figure 1. Dual chamber MFC

\section{MFC operation}

All MFCs were operated under ambient temperature conditions in the laboratory $\left(20 \pm 3^{\circ} \mathrm{C}\right)$ with a $1000 \Omega$ resistor. Nitrogen gas was flushed for $5 \mathrm{~min}$ into the anodic chamber to remove dissolved oxygen in order to maintain anoxic conditions. Polarization curves were obtained by using varying external resistance from 2000 to $100 \Omega$, cell voltage data were recorded ever $10 \mathrm{~min}^{[12]}$ for each resistance with a digital multmeter (VC88E, Shenzhen Victor Hi-tech CO, LTD. China). The polarization curves of the MFC with the fouled membrane were plotted at least three times.

COD was measured according to potassium permanganate method (HI/T399-2007). Dissolved oxygen analyzer (HACH sensION6) was placed in the anode chamber. And the water was flushed with nitrogen gas to remove DO. The cathode chamber was continuously aerated to maintain the saturated DO concentration. The mass transfer coefficient of oxygen in the membrane, $\mathrm{k}_{\mathrm{o}}$, was determined by monitoring the DO concentration over time and using the equation by Kim and co-workers ${ }^{[20]}$

$k_{o}=-\frac{V}{A t} \ln \left[\frac{C_{0}-C_{1}}{C_{0}}\right]$

Where $\mathrm{V}$ is the liquid volume in the anode chamber, $\mathrm{A}$ is the membrane cross-sectional area, $\mathrm{c}_{0}$ is the saturated oxygen concentration in the cathode chamber and $\mathrm{c}_{1}$ is the DO in the anode chamber at time $t$. The diffusion coefficient $\mathrm{D}_{\mathrm{o}}$ was calculated as $\mathrm{D}_{\mathrm{o}}=\mathrm{k}_{\mathrm{o}} * \mathrm{~L}$, where $\mathrm{L}$ is the membrane thickness.

D. Analysis

1) Scanning electron microscope (SEM) and energy dispersive $X$-ray spectrometry $(E D X)$ analysis

For SEM analysis, part of the fouled membrane was cut into pieces and immersed in $2.5 \%$ glutaraldehyde for $1 \mathrm{~h}$. They were then subjected to dehydration using a serial diluted ethanol $(30 \%, 50 \%, 70 \%, 80 \%$ and $90 \%, 15 \mathrm{~min}$ for each concentration; $100 \%, 15 \mathrm{~min}$ twice) and then dried completely at ambient temperature. The microscopic structure and elemental components of the membrane surface was analyzed using JSM-200CX SEM (JEOL Co., Japan) equipped with an EDX.

\section{2) Fourier transform infrared (FTIR) spectral analysis}

The fouling layer on the membrane was characterized with FTIR spectroscopy. The FTIR spectra of the raw and fouled membrane samples were recorded with the attenuated total reflectance (ATR) technique. FTIR-ATR measurements were conducted on a fourier transform infrared spectrometer (NEXUS870, NICOLET Co., America) equipped with an ATR accessory. The membrane samples were vacuum dried at ambient temperature of $25^{\circ} \mathrm{C}$ for $30 \mathrm{~min}$ to remove the absorbed water in samples.

\section{E. Calculation}

The COD removal effeciency ( $\xi$ COD) during operation was calculated using

$$
\xi \mathrm{COD}=\mathrm{COD}_{\text {int }} / \mathrm{COD}_{\text {out }} \times 100 \%
$$

$\mathrm{COD}_{\text {int }}$ and $\mathrm{COD}_{\text {out }}$ denote the initial and final concentrations $\left(\mathrm{mg} \cdot \mathrm{l}^{-1}\right)$, respectively.

The voltage difference between the anode and cathode (V) was recorded every day using a digital multmeter. Power density $\left(\mathrm{W} \mathrm{m}^{-3}\right)$ was calculated according to

$\mathrm{P}=\mathrm{IU} / \mathrm{V}$

Where $\mathrm{I}$ is the current, $\mathrm{U}$ is the voltage, and $\mathrm{V}$ is the volume of anode.

The Coulombic efficiency was calculated as

$$
\mathrm{CE}(\%)=\mathrm{C}_{\mathrm{P}} / \mathrm{C}_{\mathrm{T}} \times 100 \%
$$

where $C_{P}$ is the total coulombics calculated by integrating the current over time and $\mathrm{C}_{\mathrm{T}}$ is the theoretical 
amount of coulombics based on the COD removed by assuming 4 mol of electrons per mol of COD.

The polarization curves were used to evaluate the maximum power and the internal resistance. For the linear polarization curve, the relationship between the external voltage $\left(\mathrm{E}_{\mathrm{ex}}\right)$ and current (i) can be described with following equation:

$\mathrm{E}_{\mathrm{ex}}=\mathrm{E}-\mathrm{R}_{\mathrm{in}} \mathrm{i}$

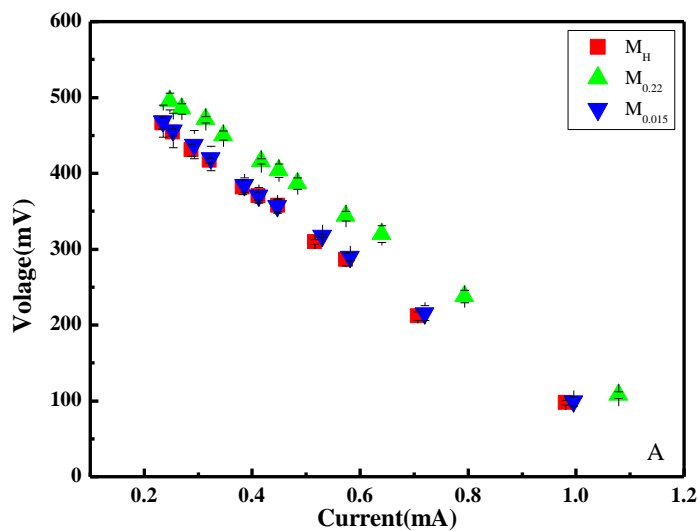

Where $\mathrm{R}_{\text {in }}$ is the total internal resistance of MFC. The intercept of the linear curve with the voltage axis, E, is referred to as the linear extrapolation open circuit voltage (LE-OCV), which is determined by extrapolation of the linear part of the polarization curve ${ }^{[21]}$.

\section{RESULT AND DISCUSSION}

\section{A. The characteristics of the MFCs}

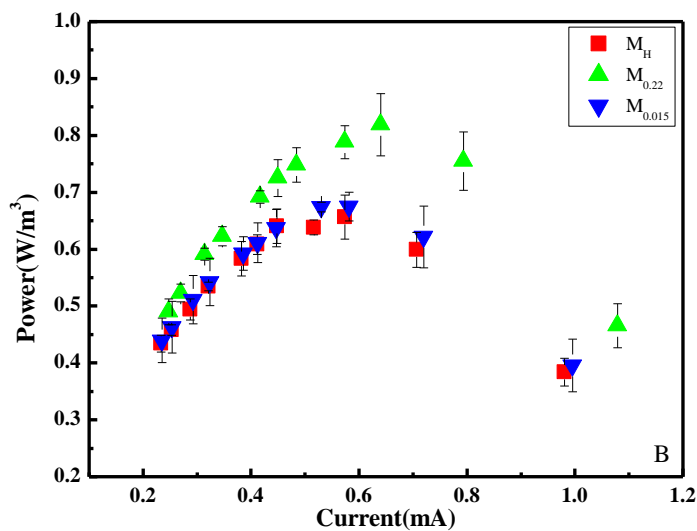

Figure 2. Polarization curves and voltage-current curves of four kinds of double-chamber MFC. (A) Voltage-current curves; (B) Polarization curves.

TABLE I COMPARISON OF THE PERFORMANCE OF MFCS WITH $\mathrm{M}_{\mathrm{H}}, \mathrm{M}_{0.22}$ AND $M_{0.015}$ IN TERMS OF MAXIMAL POWER DENSITY, INTERNAL RESISTANCE, COD REMOVAL AND CE (MEANs \pm S.D.).

\begin{tabular}{|c|c|c|c|c|}
\hline Membrane & $\begin{array}{c}\text { Maximal } \\
\text { power } \\
\text { density } \\
\left(\mathbf{m W ~ m}^{-3}\right)\end{array}$ & $\begin{array}{c}\text { Internal } \\
\text { resistance } \\
(\boldsymbol{\Omega})\end{array}$ & $\begin{array}{c}\mathbf{C O D} \\
\text { removal } \\
(\boldsymbol{\%})\end{array}$ & $\begin{array}{c}\text { Coulombic } \\
\text { efficiency } \\
(\boldsymbol{\%})\end{array}$ \\
\hline $\mathbf{M}_{\mathbf{H}}$ & $657 \pm 39$ & 531.9 & $92 \pm 2.3$ & $27.4 \pm 1.8$ \\
\hline $\mathbf{M}_{\mathbf{0 . 2 2}}$ & $819 \pm 55$ & 468.1 & $93 \pm 2.2$ & $22.9 \pm 1.9$ \\
\hline $\mathbf{M}_{\mathbf{0 . 0 1 5}}$ & $675 \pm 25$ & 509.2 & $93 \pm 2.7$ & $24.2 \pm 1.2$ \\
\hline
\end{tabular}

Polarization curves of three kinds of double-chamber MFC were showed in Fig .2B. The internal resistance of $\mathrm{M}_{\mathrm{H}}, \mathrm{M}_{0.22}$ and $\mathrm{M}_{0.015}$ was $531.9 \Omega, 468.1 \Omega$ and $509.2 \Omega$, respectively. Maximum power densities of both MFCs were $657 \pm 39 \mathrm{~mW} / \mathrm{m}^{3}, 819 \pm 55 \mathrm{~mW} / \mathrm{m}^{3}$ and $675 \pm 25 \mathrm{~mW} / \mathrm{m}^{3}$ respectively. The largest maximum power density $\left(819 \mathrm{~mW} / \mathrm{m}^{3}\right)$ was achieved in $0.22-$ SFM-MFCs.

TABLE II OXYGEN MASS TRANSFER $\left(\mathrm{K}_{0}\right)$, DIFFUSION COEFFICIENTS $\left(\mathrm{D}_{0}\right)$ IN MFC WITH DIFFERENT SEPARATORS

\begin{tabular}{|c|c|c|c|}
\hline Membranes & $\mathbf{M}_{\mathbf{H}}$ & $\mathbf{M}_{\mathbf{0 . 2 2}}$ & $\mathbf{M}_{\mathbf{0 . 0 1 5}}$ \\
\hline $\mathrm{K}_{0}\left(10^{-4} \mathrm{~cm} / \mathrm{s}\right)$ & 2.4 & 8.3 & 3.8 \\
\hline $\mathrm{D}_{0}\left(10^{-6} \mathrm{~cm}^{2} / \mathrm{s}\right)$ & 4.56 & 10.79 & 0.38 \\
\hline Thickness $(\mathrm{mm})$ & 0.19 & 0.13 & 0.01 \\
\hline
\end{tabular}

In order to explore the influence of pore size of membranes on the protons transfer and the MFC performance, the oxygen diffusion coefficients (Do) through three kinds of membranes were measured. The oxygen diffusion coefficients and mass transfer $\left(\mathrm{K}_{0}\right)$ present in the medium (TABLE II). The $\mathrm{M}_{0.22}$ had a large aperture (Fig .4) and promoted the proton transferring easily as compared to the other two membranes. Kim ${ }^{[20]}$ demonstrated that the oxygen transfer coefficient in ultrafiltration membranes increased with the membrane pore size which may cause CE decrease. Therefore, the lowest $\mathrm{CE}$ is the $0.22 \mu \mathrm{m}-\mathrm{SFM}-\mathrm{MFC}$ but the $\mathrm{CE}$ among the three kinds membrane MFCs was similar.

B. The fouling layer on the membranes

1) Chemical information of the fouling layer

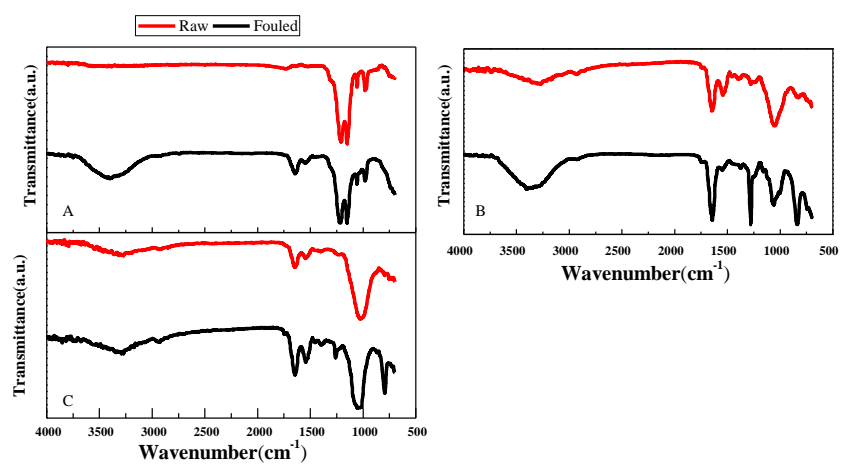

Figure. 3. FTIR spectra of the raw and the fouled membranes. (A) $M_{H}$; (B) $\mathrm{M}_{0.22}$; (C) $\mathrm{M}_{0.015}$.

MFC operation increased several new peaks on all the three separator membrane (TABLE III), while the numbers of new peaks were higher on PEM than that of $\mathbf{M}_{0.22}$ and $\mathbf{M}_{0.015}$, indicating that the PEM was seriously fouled than the other two membranes. 
TABLE III INFRARED ABSORPTION BANDS OF THE FOULING LAYER ON THE MEMBRANE

\begin{tabular}{|c|c|c|c|c|c|c|c|}
\hline \multirow{3}{*}{$\begin{array}{c}\text { Wave } \\
\text { number } \\
\left(\mathbf{c m}^{-1}\right)\end{array}$} & \multicolumn{6}{|c|}{ Membrane in the peak } & \multirow{3}{*}{ Vibration type } \\
\hline & \multicolumn{2}{|c|}{$M_{H}$} & \multicolumn{2}{|c|}{$M_{0.22}$} & \multicolumn{2}{|c|}{$M_{0.015}$} & \\
\hline & Raw & Fouled & Raw & Fouled & Raw & Fouled & \\
\hline 3290 & & $\sqrt{ }$ & $\sqrt{ }$ & $\sqrt{ }$ & $\sqrt{ }$ & $\sqrt{ }$ & Stretching vibration of $\mathrm{O}-\mathrm{H}^{[22]}$ \\
\hline 1650 & & $\sqrt{ }$ & $\sqrt{ }$ & $\sqrt{ }$ & $\sqrt{ }$ & $\sqrt{ }$ & $\begin{array}{l}\text { Stretching vibration of Amide I }(\mathrm{C}=\mathrm{O}) \text { and Amide II }(-\mathrm{NH}-) \text { in } \\
\text { proteins }\end{array}$ \\
\hline 1220 & & $\sqrt{ }$ & & $\sqrt{ }$ & & $\sqrt{ }$ & Stretching vibration of $\mathrm{P}=\mathrm{O}^{[22]}$ \\
\hline 1180 & & $\sqrt{ }$ & & $\sqrt{ }$ & & & Stretching vibration of C-N-C $\mathrm{C}^{[23 ; 24]}$ \\
\hline 1150 & $\sqrt{ }$ & $\sqrt{ }$ & & $\sqrt{ }$ & & $\sqrt{ }$ & Stretching vibration of $\mathrm{CF}_{2}$ and $\mathrm{C}-\mathrm{O}^{[22]}$ \\
\hline 1060 & & $\sqrt{ }$ & $\sqrt{ }$ & $\sqrt{ }$ & $\sqrt{ }$ & $\sqrt{ }$ & Stretching vibration of S-O ${ }^{[23 ; 24]}$ \\
\hline 1010 & & $\sqrt{ }$ & & $\sqrt{ }$ & & & Stretching vibration of $\mathrm{SO}_{3} \mathrm{H}^{[23 ; 24]}$ \\
\hline 980 & & $\sqrt{ }$ & & $\sqrt{ }$ & & $\sqrt{ }$ & Stretching vibration of C-O-C and $\mathrm{CFRCF}_{3}{ }^{[25]}$ \\
\hline
\end{tabular}

\section{2) SEM and EDX characterizations fouled membranes}

The morphology of the fouling layer of the membranes used in the MFC was imaged using SEM. The SEM images show that the fouling layer consisted of microbial extracellular polymeric substance matrix, which were originated from the microbial adhesion to the membrane to anode side ${ }^{[14]}$ (Fig .4). Since the pore size of $\mathrm{M}_{0.22}$ was bigger than that of other two membranes, it possibly overcome the problem of blockage and reduced the membrane resistance (TABLE I) ${ }^{[18]}$.
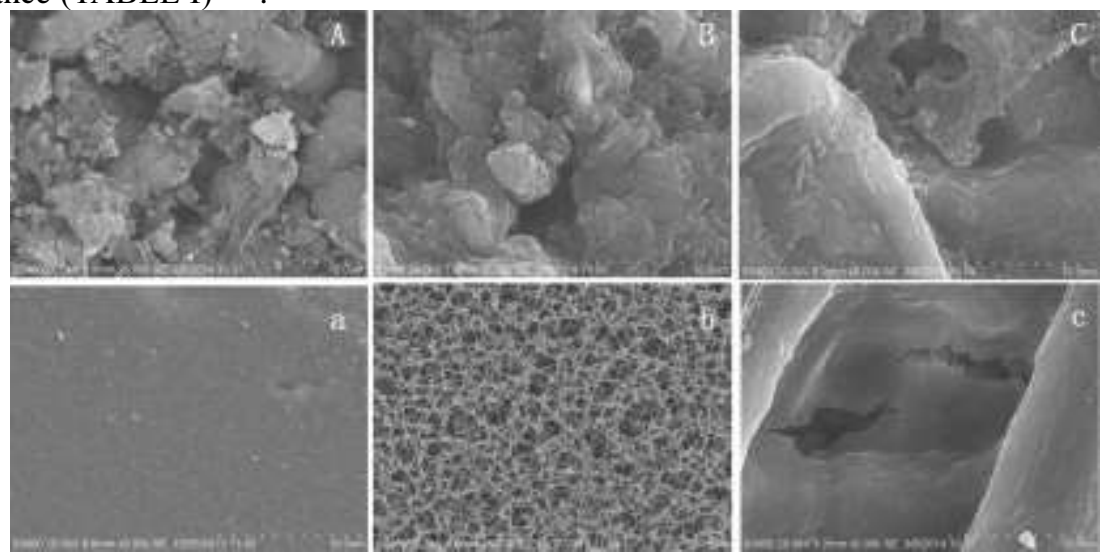

Figure. 4 SEM image of the layers on the membranes contain raw and fouled (after 45-day operation of MFC) ones. (A) Fouled $\mathrm{M}_{\mathrm{H}}$; (B) Fouled $\mathrm{M}_{0.22}$; (C) Fouled $\mathrm{M}_{0.015}$. (a) Raw $\mathrm{M}_{\mathrm{H}}$; (b) Raw $\mathrm{M}_{0.22}$; (c) Raw $\mathrm{M}_{0.015}$.

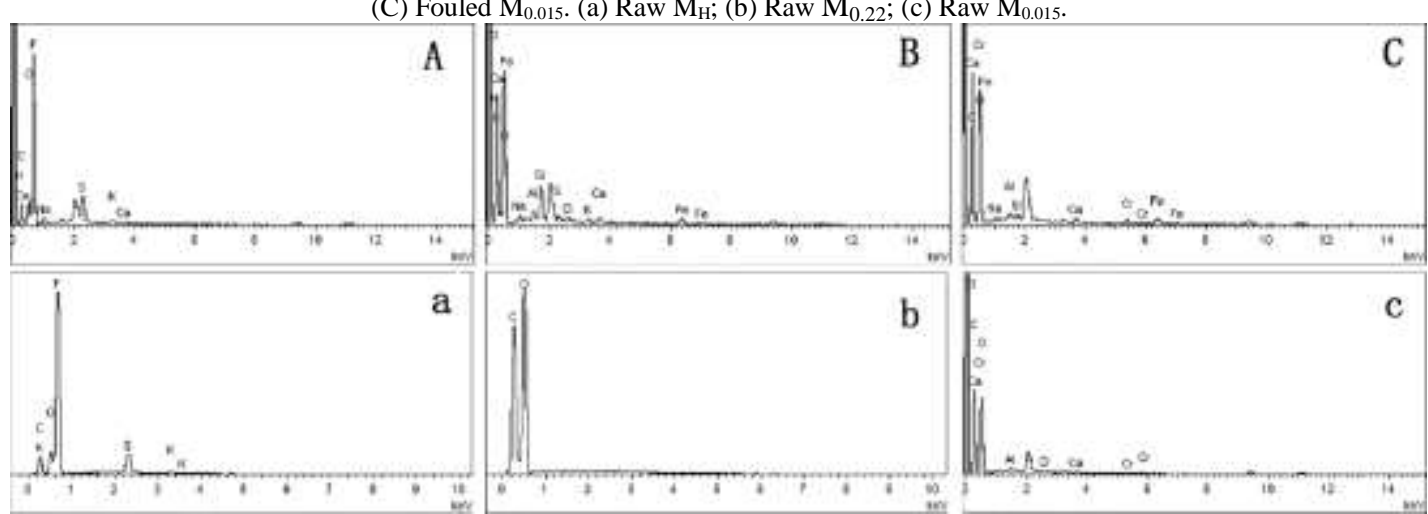

Figure. 5 EDX spectrum of the layers on the membranes contain raw and fouled (after 45-day operation of MFC) ones. (A) Fouled $\mathrm{M}_{\mathrm{H}}$; (B) Fouled $\mathrm{M}_{0.22} ;$ (C) Fouled $\mathrm{M}_{0.015}$. (a) Raw $\mathrm{M}_{\mathrm{H}}$; (b) Raw $\mathrm{M}_{0.22}$; (c) Raw $\mathrm{M}_{0.015}$. 


\section{CONCLUSION}

In this study MFCs with different membranes were investigated. The MFC results showed that $\mathrm{M}_{0.22}$-MFC exhibited the best power density $\left(819 \mathrm{~mW} / \mathrm{m}^{3}\right)$ which was $24.6 \%$ higher than that of Nafion 117. Achieved CE (22.9\%) of the $\mathrm{M}_{0.22}$-MFC was similar to that of Nafion 117. Furthermore, the cost of $\mathrm{M}_{0.22}$ is $94.5 \%$ cheaper than PEM. The achieved results demonstrate that $\mathrm{M}_{0.22}$ is a promising membrane to be applied in MFC.

\section{ACKNOWLEDGMENT}

We thank for the support from National Natural Science Foundation of China (NO. 51379063) and Jiangsu Provincial Natural Science Foundation (NO. BK2012413).

\section{REFERENCES}

[1] Mayahi A, Ilbeygi H, Ismail A F, et al. SPEEK/cSMM membrane for simultaneous electricity generation and wastewater treatment in microbial fuel cell[J]. Journal of Chemical Technology and Biotechnology, 2015.

[2] Habermann W, Pommer E. Biological fuel cells with sulphide storage capacity $[\mathrm{J}]$. Applied microbiology and biotechnology, 1991, 35(1): 128-133.

[3] Timmers R A, Strik D P, Hamelers H V, et al. Electricity generation by a novel design tubular plant microbial fuel cell[J]. Biomass and Bioenergy, 2013, 51: 60-67.

[4] Hyeonjin J, Yunghun Y, Kumaran R, et al. Production of algal biomass (Chlorella vulgaris) using sediment microbial fuel cells $[\mathrm{J}]$. Bioresource Technology, 2012, 109: 308-311.

[5] Kaur A, Kim J R, Michie I, et al. Microbial fuel cell type biosensor for specific volatile fatty acids using acclimated bacterial communities[J]. Biosensors and Bioelectronics, 2013, 47: 50-55.

[6] Donovan C, Dewan A, Heo D, et al. Sediment microbial fuel cell powering a submersible ultrasonic receiver: New approach to remote monitoring[J]. Journal of Power Sources, 2013, 233: 79-85.

[7] Chen Z, Huang Y-C, Liang J-H, et al. A novel sediment microbial fuel cell with a biocathode in the rice rhizosphere[J]. Bioresource technology, 2012, 108: 55-59.

[8] Chen C-Y, Yeh K-L, Aisyah R, et al. Cultivation, photobioreactor design and harvesting of microalgae for biodiesel production: a critical review[J]. Bioresource technology, 2011, 102(1): 71-81.

[9] Tremouli A, Antonopoulou G, Bebelis S, et al. Operation and characterization of a microbial fuel cell fed with pretreated cheese whey at different organic loads[J]. Bioresource technology, 2013, 131: 380-389.

[10] Sevda S, Dominguez-Benetton X, Vanbroekhoven K, et al. High strength wastewater treatment accompanied by power generation using air cathode microbial fuel cell[J]. Applied Energy, 2013, 105: 194-206.

[11] Zhang X, Cheng S, Wang X, et al. Separator characteristics for increasing performance of microbial fuel cells[J]. Environmental science \& technology, 2009, 43(21): 8456-8461.
[12] [12] Kim K-Y, Yang E, Lee M-Y, et al. Polydopamine Coating Effects on Ultrafiltration Membrane to Enhance Power Density and Mitigate Biofouling of Ultrafiltration Microbial Fuel Cells (UF-MFCs)[J]. Water Research, 2014.

[13] Tender L M, Gray S A, Groveman E, et al. The first demonstration of a microbial fuel cell as a viable power supply: powering a meteorological buoy[J]. Journal of Power Sources, 2008, 179(2): 571-575.

[14] Xu J, Sheng G-P, Luo H-W, et al. Fouling of proton exchange membrane (PEM) deteriorates the performance of microbial fuel cell[J]. Water Research, 2012, 46(6): 1817-1824.

[15] Jang N, Ren X, Choi K, et al. Comparison of membrane biofouling in nitrification and denitrification for the membrane bioreactor (MBR)[J]. Water Science and Technology, 2006, 53(6): 43-49.

[16] Choi M-J, Chae K-J, Ajayi F F, et al. Effects of biofouling on ion transport through cation exchange membranes and microbial fuel cell performance[J]. Bioresource Technology, 2011, 102(1): 298-303.

[17] Ghasemi M, Wan Daud W R, Ismail M, et al. Effect of pre-treatment and biofouling of proton exchange membrane on microbial fuel cell performance $[\mathrm{J}]$. international journal of hydrogen energy, 2013, 38(13): 5480-5484.

[18] Tang X, Guo $\mathrm{K}$, $\mathrm{Li} \mathrm{H}$, et al. Microfiltration membrane performance in two-chamber microbial fuel cells[J]. Biochemical Engineering Journal, 2010, 52(2): 194-198.

[19] Lovley D R, Phillips E J. Novel mode of microbial energy metabolism: organic carbon oxidation coupled to dissimilatory reduction of iron or manganese $[\mathrm{J}]$. Applied and environmental microbiology, 1988, 54(6): 1472-1480.

[20] Kim J R, Cheng S, Oh S-E, et al. Power generation using different cation, anion, and ultrafiltration membranes in microbial fuel cells[J]. Environmental Science \& Technology, 2007, 41(3): 1004-1009.

[21] Fan Y, Sharbrough E, Liu H. Quantification of the internal resistance distribution of microbial fuel cells $[\mathrm{J}]$. Environmental science \& technology, 2008, 42(21): 8101-8107.

[22] Schmitt J, Flemming H C. FTIR-spectroscopy in microbial and material analysis[J]. International Biodeterioration \& Biodegradation, 1998, 41(1): 1-11.

[23] Liang Z X, Chen W M, Liu J G, et al. FT-IR study of the microstructure of Nafion((R)) membrane[J]. Journal of Membrane Science, 2004, 233(1-2): 39-44.

[24] Gomez M a M, Perez M a B, Gil F J M, et al. Identification of species of Brucella using fourier transform infrared spectroscopy[J]. Journal of Microbiological Methods, 2003, 55(1): 121-131.

[25] Sheng G-P, Yu H-Q, Wang C-M. FTIR-spectral analysis of two photosynthetic $\mathrm{H}$-2-producing strains and their extracellular polymeric substances[J]. Applied Microbiology and Biotechnology, 2006, 73(1): 204-210.

[26] Chae K J, Choi M, Ajayi F F, et al. Mass transport through a proton exchange membrane (Nafion) in microbial fuel cells $[\mathrm{J}]$. Energy \& Fuels, 2008, 22(1): 169-176.

[27] Tang X, Guo K, Li H, et al. Microfiltration membrane performance in two-chamber microbial fuel cells $[\mathrm{J}]$. Biochemical Engineering Journal, 2010, 52(2-3): 194-198. 